\title{
IMPLEMENTASI KEBIJAKAN PENGEMBANGAN WISATA KULINER KOTA MALANG
}

\author{
Mahathir Muhammad Iqbal \\ Universitas Islam Raden Rahmat Malang \\ email: iqbal_mm@yahoo.com \\ Dadieng Kurniawan \\ Universitas Islam Raden Rahmat Malang
}

\begin{abstract}
Abstrak
Usaha Mikro Kecil dan Menengah (UMKM) khususnya di sektor kuliner butuh strategi pengembangan yang kokoh dan perlu melibatkan elemen-elemen besar sampai terkecil serta instrumen hukum yang kuat dalam memproteksi UMKM kuliner dalam negeri.Pemerintah juga harus menyelaraskan program kerjanya di tiap daerah dengan stimulan penumbuhan UMKM baru di tiap kecamatan. Oleh karena itu dibutuhkanlah suatu strategi dalam pengembangan usaha mikro kecil dan menengah khususnya di sektor kuliner di Kota Malang. Penelitian ini merupakan penelitian kualitatif. Metode ini disebut juga sebagai metode naturalistik, karena penelitiannya dilakukan pada kondisi yang alamiah (natural setting). Hasilnya, Usaha Mikro Kecil dan Menengah (UMKM) khususnya di sektor kuliner butuh strategi pengembangan yang kokoh dan perlu melibatkan elemen-elemen besar sampai terkecil serta instrumen hukum yang kuat dalam memproteksi UMKM kuliner dalam negeri.Pemerintah juga harus menyelaraskan program kerjanya di tiap daerah dengan stimulan penumbuhan UMKM baru di tiap kecamatan. Oleh karena itu dibutuhkanlah suatu strategi dalam pengembangan usaha mikro kecil dan menengah khususnya di sektor kuliner di Kota Malang.
\end{abstract}

Kata Kunci: UMKM, Wisata Kuliner, Implementasi Kebijakan

\begin{abstract}
Small and Medium Enterprises (SMEs), especially in the culinary sector need a strong development strategy and need to involve the big elements to the smallest and strong legal instruments in protecting the domestic culinary SMEs. The government also must align its work program in each region with growth stimulant New SMEs in each sub-district. Therefore it is needed a strategy in the development of micro small and medium enterprises, especially in the culinary sector in Malang. This research is a qualitative research. This method is also called as naturalistic method, because the research is done on natural conditions (natural setting). As a result, Small and Medium Enterprises (SMEs), especially in the culinary sector need a strong development strategy and need to involve the major elements to the smallest and strong legal instruments in protecting the domestic culinary SMEs. Government must also align its work programs in each region with Stimulant of new SMEs growth in each sub-district. Therefore it is needed a strategy in the development of micro small and medium enterprises, especially in the culinary sector in Malang.
\end{abstract}

Keywords: SMEs, Culinary Tour, Policy Implementation

\section{PENDAHULUAN}

Makanan dan minuman merupakan salah satu bentuk budaya tangible yang sarat dengan nilai historis dan kebijaksanaan. Makanan dan minuman merupakan gambaran simbolik kondisi sosio-ekonomi suatu kelompok. Bahkan dapat menggambarkan kondisi suatu negara. Di masa-masa sulit seperti resesi ekonomi, sajian makanan cenderung bersifat hanya untuk bertahan hidup (basic). Sebaliknya saat kondisi ekonomi stabil, dimana bahan baku dapat diperoleh lebih mudah, keragaman sajian makanan akan muncul seiring dengan kreatifitas produsen makanan dan permintaan pasar.
Sajian makan dan minuman juga menggambarkan kekayaan alam dimana suatu kelompok hidup dan menetap. Bahkan dapat pula menggambarkan suatu kelas masyarakat. Menyadari bahwa makanan dan minuman merupakan identitas kelompok dan modal simbolik dalam pergaulan anak bangsa, maka sudah sewajarnya pemahaman filosofis tentang makna Bhineka Tunggal Ika Tan Hanna Dharma Mangrwa diletakkan sebagai landasan dasar agar dalam proses evolusioner kuliner di kota Malang tetap dalam kerangka harmoni yang cantik. (Living in Harmony is Beautiful that's why you can see what the meaning of Beautiful Malang). 
Kota kreatif merupakan salah satu konsep pengembangan kota dengan cara meningkatkan sesejahteraan masyarakatnya melalui pemanfaatan kekreativitisan untuk memecahkan permasalahan bersama yang terwujud dalam sebuah aktivitas industri yaitu industri kreatif

Salah satu indikator tingkat kesejahteraan penduduk suatu wilayah adalah tingkat PDRB yang merupakan nilai bersih barang dan jasa-jasa akhir yang dihasilkan oleh berbagai kegiatan ekonomi di suatu daerah dalam suatu periode. Kota Malang merupakan kota industri, dimana sebagian besar (persentase) Pendapatan Domestik Regional Bruto (PDRB) diperoleh dari industri pengolahan dan industri perdagangan. Salah satu komponen yang menopang industri pengolahan tersebut adalah industri kuliner yang beraneka ragam.

Kuliner adalah hasil olahan yang berupa masakan, masakan tersebut bisa berupa lauk pauk, termasuk di dalamnya penganan, jajanan dan aneka minuman. Saat ini wisata kuliner sedang berkembang dalam industri pariwisata. Sektor kuliner memegang peranan penting karena mampu meningkatkan daya tarik kota tujuan wisata yang berdampak pada meningkatnya jumlah wisatawan dan mampu memperkuat identitas daerah serta menstimulasi pertumbuhan sektor lainnya.

Banyak faktor yang menggerakkan orang mau melakukan perjalanan jauh ke suatu kota, salah satunya adalah apresiasi dan kebutuhan akan kuliner berkualitas yang memiliki sejarah serta cerita di balik suatu sajian makanan. Malang sebagai kota tujuan wisata menjadi semakin menarik karena memiliki potensi besar dalam pengembangan wisata kuliner di setiap wilayahnya yang terbagi dalam 5 kecamatan. Di samping itu, banyaknya inovator kuliner di Kota Malang juga mampu melahirkan sajian kuliner yang beragam dan khas. Hal ini tentunya bisa menjadi daya tarik bagi wisatawan. Bahkan banyak wisatawan yang tertarik datang ke Kota Malang hanya untuk mencicipi suatu sajian hidangan yang unik dan lezat, mulai dari makanan tradisional hingga internasional dan juga aneka jajanan/camilan serta minuman.

Kota Malang sejatinya tidak kalah dengan daerah lainnya di Indonesia, banyak jenis makanan yang layak untuk dinikmati kelezatannya dan ditonjolkan kekhasannya. Salah satu langkah strategis untuk meningkatkan daya tarik wisatawan datang ke Kota Malang adalah dengan mempublikasikan keunggulan dan kekhasan kulinernya. Dalam konteks inilah, penulis tertarik untuk meneliti tentang "Implementasi Kebijakan Pengembangan Wisata Kuliner Kota Malang”. Adapun permasalahan yang akan dibahas adalah bagaimana implementasi kebijakan pengembangan wisata kuliner di Kota Malang.

\section{METODE}

\section{Pendekatan Penelitian}

Penelitian ini merupakan penelitian kualitatif. Metode ini disebut juga sebagai metode naturalistik, karena penelitiannya dilakukan pada kondisi yang alamiah (natural setting). Data hasil penelitian di lapangan lebih berkenaan dengan interpretasi terhadap data yang ditemukan di lapangan (interpretive). Sedangkan jenis penelitian ini adalah deskriptif, dimana peneliti berusaha menggambarkan sebaran lokasi wisata kuliner di 5 kecamatan (Kecamatan Blimbing, Kecamatan Lowokwaru, Kecamatan Klojen, Kecamatan Sukun dan Kecamatan Kedungkandang) di kota Malang dan pendapat para pelaku wisata kuliner, baik tradisional maupun internasional tentang usahanya dan kebijakan pemerintah terkait wisata kuliner di kota Malang.

\section{Populasi dan Sampel}

Populasi penelitian ini adalah para pelaku wisata kuliner yang tersebar di 5 kecamatan kota Malang. Berdasarkan data dari Dinas Pariwisata Kota Malang, jumlah pelaku wisata kuliner yang ada di kota Malang sampai akhir tahun 2015 tercatat sebanyak 508. Jumlah tersebut tersebar Di Kecamatan Blimbing sebanyak 72, di Kecamatan Lowokwaru sebanyak 193, di Kecamatan Klojen sebanyak 200, di Kecamatan Sukun dan sebanyak 12, di Kecamatan Kedungkandang 31.

Karena populasi tersebar di lima kecamatan, teknik pengambilan sampel pada masing-masing kecamatan dilakukan menggunakan stratified random sampling. Untuk mendapatkan ukuran sampel minimal dengan jumlah populasi yang telah diketahui, dipergunakan rumus Yamane (1973) dengan rumusan sebagai berikut.

$$
n=\frac{N}{N d^{2}+1}
$$

$$
\begin{aligned}
& \text { (1) } \mathrm{n} \quad=\text { Jumlah Sampel } \\
& \mathrm{N}=\text { Ukuran Populasi } \\
& \mathrm{d} \quad=\text { Presisi yang ditetapkan } \\
& 1 \text { = Angka konstanta }
\end{aligned}
$$

Sedangkan untuk menentukan alokasi unit ke dalam strata menggunakan prinsip alokasi proporsional dengan rumus sebagai berikut.

$$
n_{i}=\frac{N_{i} \times n}{N}
$$

(2) ni = Ukuran Sampel yang harus diambil dari strata

$\mathrm{Ni}=$ Ukuran Strata

$\mathrm{n}=$ Sampel Keseluruhan

$\mathrm{N}=$ Ukuran Populasi

Dengan menggunakan model rumusan Yamane di atas, jumlah sampel minimal yang harus diambil adalah sebagai berikut (menggunakan presisi/derajat error sampling sebesar $10 \%)$.

$$
\mathrm{n}=889.813 /\{(889.813 \times 0,01)+1\}
$$$$
=99,988 \sim 100 \text { responden }
$$ 
Jumlah sampel untuk setiap masing-masing kecamatan bisa dijelaskan pada tabel berikut ini: (Contoh di bawah ini diambil data jumlah penduduk)

Tabel 1. Proses Sampling

\begin{tabular}{ll}
\hline Kecamatan & $\begin{array}{c}\text { Pelaku } \\
\text { Kuliner }\end{array}$ \\
\hline Blimbing & 72 \\
Klojen & 200 \\
Kedungkandang & 31 \\
Sukun & 12 \\
Lowokwaru & 193 \\
Jumlah & 508 \\
\hline Sumber: data primer diolah
\end{tabular}

Dari sebanyak 100 orang responden yang dijadikan sampel penelitian tersebut, sampel kemudian ditentukan menggunakan metode purposive sampling. Metode purposive sampling merupakan metode pengambilan sampel berdasarkan kriteria tertentu, disesuaikan dengan tujuan penelitian. Kriteria yang digunakan tersebut antara lain:

1. Responden memiliki usaha wisata kuliner yang unik/khas dan termasuk dalam salah satu klasifikasi wisata kuliner yang dijelaskan dalam bab II.

2. Responden telah menjalankan usaha wisata kulinernya minimal selama 5 tahun, dengan tujuan agar supaya memiliki penilaian yang lebih objektif mengenai perkembangan wisata kuliner dan kebijakan pemerintah pemerintah terkait wisata kuliner di kota Malang

\section{Teknik Pengumpulan Data}

Teknik pengumpulan data yang digunakan dalam penelitian ini adalah:

1. Wawancara semi struktur dengan para pelaku wisata kuliner yang tersebar di 5 kecamatan kota Malang.

2. Wawancara tidak terstruktur dengan tokoh masyarakat pecinta kuliner dan pemerhati di bidang wisata kuliner baik tradisional maupun internasional.

Dokumentasi, dilakukan dengan mengambil gambar aneka sajian makanan, minuman dan jajanan serta oleh-oleh khas Malang.

\section{HASIL DAN PEMBAHASAN}

\section{Sinergitas Pengembangan Malang Raya}

Kepariwisataan merupakan sektor kegiatan yang sangat strategis, terbukti banyak negara yang menempatkan penyelenggaraan pariwisata sebagai sektor perdagangan jasa andalan dalam perolehan devisa dan penggerak perekonomian masyarakat. Hal ini sangat beralasan sebab sektor pariwisata sebagai industri jasa yang tidak memiliki keterbatasan (borderless) seperti:

1. Tidak dapat dibatasi dengan wilayah

2. Tidak ada pembatasan quota produk

3. Tidak ada keterbatasan bahan baku/tidak habis dikonsumsi

4. Tidak termasuk dalam katagori industri padat modal

Salah satu misi Walikota Malang tahun 2013-2018 adalah "membangun kota Malang sebagai tujuan wisata yang aman, nyaman dan berbudaya". Dalam upaya menjadikan Kota Malang sebagai salah satu tujuan wisata, maka perlu ada upaya peningkatan citra Kota Malang sebagai Kota Pariwisata. Selama ini pencitraan kota pariwisata dinilai masih belum optimal, meskipun jumlah wisatawan baik lokal mapun asing mengalami peningkatan dari tahun ke tahun. Belum optimalnya pencitraan tersebut terkait dengan beberapa isu diantaranya:

1. Sektor pariwisata merupakan sektor yang sangat diharapkan oleh pemerintah Kota Malang untuk menjadi motor penggerak roda perekonomian, sampai saat ini masih kalah perannya dibanding sektor industri dan pendidikan;

2. Citra Kota Malang sebagai kota pariwisata sudah terbangun sejak dulu, namun pariwisata masih cenderung diartikan secara sempit, sehingga wisata belanja, wisata kuliner bahkan wisata pendidikan masih belum dipromosikan secara optimal.

Oleh karena itu, dalam upaya menjadikan Daerah Tujuan Wisata (DTW) unggulan, Kota Malang terus melakukan berbagai strategi pengembangan industri pariwisata melalui pengembangan kawasan wisata belanja atau souvenir, seperti pusat perbelanjaan, baik yang bersifat tradisional maupun modern yang tersebar di berbagai penjuru Kota Malang. Pemerintah Kota Malang juga membangun strategi pemasaran pariwisata baru melalui pengembangan potensi wisata MICE (Meeting, Incentive and Exhibition).

Untuk membangun kota wisata yang nyaman bagi wisatawan, maka perlu penyediaan sarana dan prasarana infrastruktur yang memadai, jalan bebas banjir dan macet, parkir nyaman, peningkatan kualitas pelayanan dari semua stakeholder pariwisata, ketersediaan produk lokal sebagai oleh-oleh khas Malang, lingkungan yang bersih dengan udara segar, dan tersedia pusat informasi wisata. Semua kebutuhan ini bisa terpenuhi jika Pemerintah daerah memiliki komitmen yang kuat untuk mewujudkan Kota Malang sebagai daerah tujuan wisata. Penanganan pariwisata seharusnya tidak dibebankan pada Dinas Kebudayaan dan Pariwisata semata, namun juga menjadi tanggungjawab multi SKPD, seperti:

1. Dinas Pekerjaan Umum: penyediaan sarana infrastruktur yang memadai

2. Badan Lingkungan hidup: pemenuhan ruang terbuka hijau (RTH) 30\%

3. Dinas Kebersihan dan Pertamanan: kebersihan dan keindahan kota

4. Dinas Informasi dan Komunikasi: penyediaan internet, intranet dan sarana infrastruktur telematika untuk memudahkan akses informasi bagi wisatawan

5. Dinas Koperasi dan UKM: pemberdayaan UKM

6. Dinas perindustrian dan Perdagangan: masalah perijinan usaha

7. Dinas Perhubungan: perparkiran, terminal dan angkutan kota yang nyaman

8. Dinas pasar: kebersihan dan kenyamanan pasar sebagai salah satu tujuan wisata belanja, penataan dan pembinaan PKL. 
9. Dinas Pendidikan: penyedia wisata pendidikan, termasuk juga menjadi tanggung jawab Perguruan Tinggi

Pariwisata Kota Malang merupakan salah satu prioritas pembangunan yang ada di Kota Malang. Mengingat Kota Malang memiliki berbagai macam obyek wisata. Hal ini bisa kita telusuri melalui PERWAL Nomor 34 Tahun 2014 Tentang Rencana Induk Pengembangan Wisata Daerah.

Jika kita menelusuri RIPPDA tersebut, kita akan mengetahui bahwa prinsip arah pembangunan kepariwisataan di Kota Malang meliputi:

1. pembangunan kepariwisataan yang berkelanjutan;

2. orientasi pada upaya-upaya pertumbuhan, peningkatan kesempatan kerja, pengurangan kemiskinan, serta pelestarian lingkungan;

3. dilaksanakan dengan tata kelola yang baik;

4. dilaksanakan secara terpadu secara lintas sektor, lintas daerah, dan lintas pelaku; dan

5. dilaksanakan dengan mendorong kemitraan sektor publik dan privat.

Di sisi lain pengembangan pariwisata berada pada area tatanan wilayah administrasi Pemerintahan Daerah yang memiliki otoritas dan otonomi daerah yang mempunyai implikasi luas terhadap pengembangan pariwisata. Dalam pengembangan potensi wisata akan terjadi saling ketergantungan antara daerah yang satu dengan daerah yang lain. Pertanyaan yang layak diajukan adalah: apakah kerjasama antar daerah di Malang Raya (Kabupaten Malang, Kota Malang, Kota Batu) dalam pengembangan potensi wisata sudah dilakukan oleh Pemerintah Kota Malang, sehingga terjadi sinergitas sebagaimana yang diamanahkan dalam RIPPDA Kota Malang, terutama pada point "f".

Tiga daerah kawasan wisata Malang Raya yaitu Kabupaten Malang, Kota Malang dan Kota Batu merupakan salah satu daerah wisata di Provinsi Jawa Timur yang memiliki berbagai kesamaan dan keunikan potensi Objek dan Daya Tarik Wisata (ODTW). Potensi unggulan yang tersebar di ketiga daerah tersebut dapat dilakukan pengembangan melalui kerjasama antar ketiga daerah dengan melakukan kesepahaman paket regulasi dan program kegiatan untuk pengembangan ODTW serta berbagai deversifikasi kerjasama lain.

Dalam implementasi pengembangan pariwisata antar daerah di kawasan Malang Raya dapat dilihat kondisi sebagai berikut: Kerjasama pengembangan pariwisata antar daerah di Malang Raya pada umumnya masih bersifat wacana dan konsep yang telah dipahami bahwa kerjasama dalam rangka pengembangan pariwisata akan berpengaruh terhadap pengembangan ekonomi masing-masing daerah. Akan tetapi realisasi dari wacana tersebut belum pernah termanifestasikan.

Kurangnya pemahaman antar instansi tentang kerjasama pengembangan wisata Malang Raya dan berdasar pengamatan hanya dipahami sebatas wacana kerjasama untuk mengembangkan pariwisata antar daerah.

Untuk mewujudkan kerjasama pengembangan kawasan wisata Malang Raya secara nyata perlu diketahui peta kebutuhan kerjasama pengembangan pariwisata antar daerah yang meliputi:

1. Komitmen bersama dari masing-masing daerah untuk membangun kerjasama yang sinergis dalam pengembangan ODTW agar lebih optimal dan saling menjaga konsistensi kerjasama, serta adanya pemahaman kerangka pikir yang sama antar instansi, antar eksekutif dan legislatif masing-masing daerah maupun kesamaan pikir antar instansi, eksekutif dan legislatif antar daerah yang melakukan kerjasama, serta masyarakat daerah yang menjadi stakeholder dalam pengembangan kawasan wisata.

2. Kesepakatan kerjasama hendaknya diikuti dengan kebijakan riil dari masing-masing daerah yang terdokumentasi secara resmi dalam RIPPDA masingmasing daerah dan RIPPDA bersama, serta tindakan konkret untuk mengimplementasikan kerjasama. Dan hal tersebut akan terwujud jika ditunjang dengan adanya usaha efektif untuk mengubah paradigma semangat ego-sektoral dan ego-kedaerahan menjadi paradigma kebersamaan.

3. Dalam segala tindakan dan kegiatan agar selalu mengikutsertakan peran serta masyarakat untuk mendapat dukungan luas dari masyarakat antar daerah dalam proses pengambilan kebijakan maupun dalam pelaksanaan kerjasama pengembangan kawasan pariwisata antar daerah.

4. Adanya diskresi kebijakan yang tepat dari lembaga yang berwenang melakukakan koordinasi ditingkat propinsi.

5. Untuk mengakomodasi akselerasi proses kerjasama pengembangan kawasan pariwisata antar daerah, perlu dibangun forum jaringan komunikasi daerah dan antar daerah hingga tingkat desa yang melibatkan masyarakat, LSM, pejabat pemerintah, dan anggota DPRD dalam rangka membangun kesepahaman terhadap urgensitas pengembangan kawasan pariwisata melalui kerjasama antar daerah.

Di sisi lain dibutuhkan mekanisme kontrol yang transparan yang melibatkan berbagai stake holder sehingga diketahui segala eksternalitas dari sisi ekonomi, sosial budaya sebagai konsekuensi dilakukannya kerjasama.

Terdapat 3 eksternalitas prospektif yang diharapkan berdampak positif dari pengembangan jaringan kerjasama di kawasan Malang Raya: Pertama, sebagai sarana pemberdayaan ekonomi masyarakat lokal maupun antar daerah dengan pengembangan paket-paket wisata yang memiliki prospektif terhadap pertumbuhan ekonomi masyarakat kearah pengembangan paket wisata yang berada pada wilayah lintas batas antar daerah yang menjadi tujuan wisata.

Kedua, sebagai sarana meredam konflik kepentingan antar daerah dimana konflik kepentingan antar daerah di Malang Raya masih merupakan permasalahan sampai saat ini dan belum mendapat penyelesaian dengan baik. Melalui kerjasama berbagai kepentingan untuk pengembangan pariwisata tersebut dapat diwadahi dalam suatu forum dengan nomenklatur badan atau apa saja untuk kepentingan bersama dengan difasilitasi oleh Pemerintah Provinsi Jawa Timur. Ketiga, 
sebagai sarana mekanisme efisiensi dalam mengembangkan sektor pariwisata antar daerah dengan cara mengalihkan pengembangan sektor pariwisata yang bukan unggulan untuk kepentingan sektor lain yang lebih urgen dan lebih murah biayanya.

\section{Pola Kemitraan}

Pemerintah dengan segala keterbatasannya tidak dapat melakukan sendiri dalam pengembangan industri pariwisata karena keterbatasan-keterbatasan yang dimiliki pemerintah baik itu dalam bidang kapital atau modal, sumber daya manusia (SDM) ataupun bidang manajemennya. Dengan demikian pemerintah harus melakukan kerja sama atau bermitra dengan aktor lain yaitu sektor privat (swasta) maupun masyarakat. Masyarakat akan menjadi bagian penting yang tidak terpisahkan dalam pengembangan kepariwisataan, serta dapat menumbuhkan sikap memiliki dan rasa tanggung jawab sebagai pelaku dan penentu pengembangan kepariwisataan utamanya dalam skala lokal begitupun dengan sektor privat (swasta).

Kebutuhan kemitraan dengan melibatkan negara, swasta dan lembaga social kemasyarakatan baik di tingkat lokal dan internasional menjadi kebutuhan yang urgen bagi pemerintah. Dalam posisi seperti ini, kebijakan negara sangat bermakna, tidak saja sebagai fungsi regulatif dalam negeri tetapi juga fungsi strategis dalam hubungan internasional. Dengan demikian, maka kebijakan pengembangan pariwisata di satu negara tidak dapat dianalisis tanpa mengkaitkan dengan kepentingan kemitraan antar pemerintah, bisnis dan masyarakat.

Kebijakan kelembagaan kemitraan antara pemerintah, masyarakat dan swasta, merupakan satu sistem yang saling berinteraksi dengan batasan-batasan dan aturanaturan yang telah disepakati antar berbagai pihak yang bermitra. Dan kemitraan ini dikembangkan dalam kerangka kebutuhan dan sumber daya yang dimiliki oleh pihak yang bermitra ini.

Dalam model kemitraan 3 (tiga) pihak antara Pemerintah, Privat Sektor, dan masyarkat, masingmasing pihak memiliki peran dan manfaat sendiri-sendiri:

1. Dalam hubungan kemitraan pemerintah dan swasta maka pemerintah berperan menyusun kebijakan dan aturan main serta menyediakan pelayanan perizinan, dan pengembangan kerjasama antara daerah dimana memungkinkan pelaku bisnis di daerah masingmasing bisa saling mengembangkan investasi. Sedangkan dari pihak swasta, kemitraan akan mendorong peran swasta untuk memberikan lingkungan kondusif daerah sebagai daerah tujuan investasi, pelibatan departemen terkait (industri, tenaga kerja, dan sebagainya), serta kebutuhan untuk transparansi dalam hubungan perizinan dan nilai tambah yang dapat diperoleh dari kegiatan ekonomi lokal.

2. Dalam hubungan kemitraan pemerintah dan komunitas (masyarakat) maka pemerintah berperan menyusun kebijakan yang memihak kepada kepentingan masyarakat, serta melakukan transparansi dan akuntabilitas publik. Sedangkan bagi masyarakat sendiri kemitraan menjadi peluang bagi masyarakat untuk mendapatkan kesempatan usaha, dan memperoleh ruang untuk melakukan negosiasi kepada pemerintah dalam memperoleh keadilan dan kesetaraan.

Di Indonesia, kebijakan kemitraan dalam pengembangan pariwisata pembahasan secara mendalam isu tentang Public and Private Sector Partnership di bidang pariwisata mengemuka dalam Simposium pariwisata di Yogjakarta pada tahun 2001. Kegiatan ini merupakan bagian dari pertemuan East Asian InterRegional Tourism Forum (EATOF) Tahunan.

Secara umum dalam kebijakan kemitraan di bidang pariwisata telah dirumuskan pemerintah dalam UU No 10 Tahun 2009 Tentang Kepariwisataan (Lihat Dalam Pasal 17) yang berbunyi:

"Pemerintah dan Pemerintah Daerah wajib mengembangkan dan melindungi usaha mikro, kecil, menengah, dan koperasi dalam bidang usaha pariwisata dengan cara:

1. membuat kebijakan pencadangan usaha pariwisata untuk usaha mikro, kecil, menengah, dan koperasi dan

2. menfasilitasi kemitraan usaha mikro, kecil, menengah, dan koperasi dengan usaha skala besar.

Namun demikian, kebijakan ini belum dirumuskan secara lebih operasional mencakup batasan ruang lingkup kemitraan yang dapat dilakukan pemerintah, mekanisme dan kedudukan masing-masing aktor yang terlibat, serta pedoman implementasinya.

Tetapi sayang, dalam perspektif Kota Malang Pengusaha kuliner belum merasa menjadi bagian dari penyusunan kebijakan pariwisata sehingga mereka hanya memahami dirinya sebagai objek pajak semata. Padahal point "e" pada RIPPDA mengamanahkan pemgembangan wisata dilaksanakan dengan mendorong kemitraan sektor publik dan privat..

\section{PENUTUP}

\section{Simpulan}

Usaha Mikro Kecil dan Menengah (UMKM) khususnya di sektor kuliner butuh strategi pengembangan yang kokoh dan perlu melibatkan elemen-elemen besar sampai terkecil serta instrumen hukum yang kuat dalam memproteksi UMKM kuliner dalam negeri.Pemerintah juga harus menyelaraskan program kerjanya di tiap daerah dengan stimulan penumbuhan UMKM baru di tiap kecamatan. Oleh karena itu dibutuhkanlah suatu strategi dalam pengembangan usaha mikro kecil dan menengah khususnya di sektor kuliner di Kota Malang. Malang Raya merupakan terminologi dari eks-keresidenan Malang, yaitu Kabupaten Malang, Kota Batu dan Kota Malang.Kota Malang sendiri tumbuh sebagai Kota Metropolitan di Jawa Timur.Malang memiliki daya tarik dari kekayaan sumber daya alam serta temperatur yang mempengaruhinya. Itu sebabnya, menurut Dinas Kebudayan dan Pariwisata, rasa tempe Malang tentulah 
berbeda dengan tempe Blitar, walaupun sama-sama berbahan dasar dari kedelai dan hasil akhirnya tempe, tetapi suhu yang menjadi komposisi dalam prosesnya sangat berpengaruh. Usaha kuliner di Kota Malang yang tumbuh juga menarik perhatian masyarakat Indonesia. Selain Kota Pendidikan dan Kota Pariwista, Malang memiliki daya tarik di sisi kulinernya.Banyak PKL yang merajalela dibeberapa jalan besar di Kota Malang. Salah satunya di sekitar Jalan Ijen, yang mana Jalan Ijen merupakan peninggalan rumah keluarga Bangsa Belanda. Pola pertumbuhan ekonomi terbentuk karena ada daya tarik gayacentripetal yang menarik kegiatan ekonomi serta sosial untuk berlokasi secara terpusat dan kolektif demi mendapatkan manfaat aglomerasi diantaranya economies of scale.

\section{Saran}

Saatnya membangkitkan ekonomi lokal di Kota Malang, dengan mendorong Usaha Mikro, kecil, dan Menengah (UMKM), terutama dalam bidang kuliner. UMKM merupakan fondasi penting dalam pembangunan dan kemandirian ekonomi daerah karena mampu menyerap tenaga kerja yang signifikan, serta mendorong peningkatan kesejahteraan.

Oleh karena itu, usaha-usaha untuk mendorong masyarakat mencintai produk lokal Kota Malang patut diapresiasi. Saat ini di Kota Malang tersebar sentra-sentra wisata kuliner. Namun perlu disadari, sentra-sentra tersebut masih perlu dikembangkan secara lebih baik agar mampu berdaya saing dan memberikan nilai tambah bagi sektor pariwisata. Minimal, ada empat aspek penting bagaimana harus mengembangkan sentra-sentra ini.

Pertama, sentra kuliner harus didukung dengan permintaan lokal yang tinggi. Hal ini dapat didorong dengan dukungan konsumsi atau pembelian produkproduk kuliner lokal si setiap event-event besar. Bahkan dibeberapa tempat pusat perbelanjaan, diwajibkan menggunakan produk kuliner lokal sebagai bagian dalam penjualan mereka.

Kedua, sentra kuliner harus didukung dengan kualitas dan kuantitas sumber daya manusia (SDM), teknologi, dan sumber daya alam (SDA) yang mendukung. Hal ini untuk mendukung produk-produk sentra kuliner yang berkualitas, dalam aspek: desain produk, promosi, penggunaan teknologi, dan efisiensi biaya.

Ketiga, sentra-sentra kuliner harus memiliki UMKM yang banyak untuk mendorong persaingan yang lebih sehat agar mampu berkompetisi dengan baik antar UMKM di sentra tersebut. Kompetisi yang sehat bukan untuk saling menjatuhkan, tapi lebih diarahkan pada kompetisi dalam melahirkan teknologi dan inovasi produk baru, serta inovasi dalam hal strategi pemasaran.

Terakhir, sentra-sentra kuliner harus diduk industri-industri lain yang mendukung. Dengan kata lain, industri-industri yang terkait harus didorong melakukan kolaborasi guna mendorong potensi-potensi kuliner yang ada. Hal ini jugalah yang harus menjadi perhatian para pelaku dan penggiat UMKM, jika ingin mengembangkan sentra-sentra kuliner yang ada.

Suksesnya sebuah kegiatan bagi UMKM harus konsisten dengan pengembangan visi mendorong sentrasentra kuliner yang sudah ada atau melahirkan sentrasentra baru sebagai kekuatan ekonomi yang kuat.

Sentra-sentra kuliner tersebut harus didorong kearah penggunaan teknologi yang semakin efisien. Pihak perguruan tinggi harus menjadi bagian dari kolaborasi tersebut, dimana penelitian dan pengabdian masyarakat yang ada di Universitas harus terlibat dalam pengembangan sentra-sentra kuliner lokal.

\section{DAFTAR PUSTAKA}

Astuti, Sri dan Himasari Hanan. 2012. The behaviour of consumer society in consuming food at restaurants and cafes. Procedia - Social and Behavioral Sciences 42: 429-435.

Blythe, Jim. 2008. Essentials of Marketing Communications. Prentice Hall.

Communication and Development Class (ComDevers). 2013. Research handbook for communication \& development. First Edition. Athens: Yamada International House.

Eravia, Diana, Juliana dan Tri Handayani. 2015. The opportunities and threats of small and medium enterprises, in Pekanbaru: comparison between SMEs in food and restaurant industries. Procedia - Social and Behavioral Sciences; 169: 88 - 97.

Kota Malang pionir wisata halal. (2016, Juni 5). Jawa Pos-Radar Malang, h.29.

Lianty. 2011. Konsep marketing public relations (MPR): Definisi dan peran marketing public relations. Diakses pada tanggal 11 Agustus 2016, dari http://webcache.googleusercontent.com/search?q=cac he:4arMbloi-pQJ:jurnal-sdm.blogspot.com/2009/08/ konsep-marketing-public-relations-mpr.html+\&cd= $1 \& \mathrm{hl}=\mathrm{id} \& \mathrm{ct}=\mathrm{clnk} \& \mathrm{gl}=\mathrm{id}$

Mak, Athena H. N., etc. 2012. Factors influencing tourist food consumption. International Journal of Hospitality Management; 31: 928-936.

Megawati, R. 2009. Studi pengembangan pusat jajanan di pasar pagi Karangwaru sebagai salah satu aset wisata kuliner kota Yogyakarta. Yogyakarta: Pemerintah Kota Yogyakarta.

MUI perlonggar sertifikasi halal. (2016, Juni 6). Jawa Pos-Radar Malang, h.35.

Sengel, Tarik, etc. 2015. Tourists' approach to local food. Procedia - Social and Behavioral Sciences; 195: $429-437$.

Sharif, Mohd Shazali Md, etc. 2013. How could the transfer of food knowledge be passed down?. Procedia-Social and Behavioral Sciences; 105: 429 437. 
Shimp, Terence A. 2010. Advertising, Promotion, \& Other Aspects of Integrated Marketing Communications, $8^{\text {th }}$ Edition, Cengage Learning.

Shin, Kwang-Yong. 2013. The Executor of Integrated Marketing Communications Strategy: Marcom Manager's Working Model, Springer.

Stanley, John and Stanley, Linda. 2015. Food Tourism_A Practical Marketing Guide, CABI Publishing

Yamane, T. 1973. Statistic an introduction analysis. Third Edition. Tokyo: Aoyama Gakuin University. 